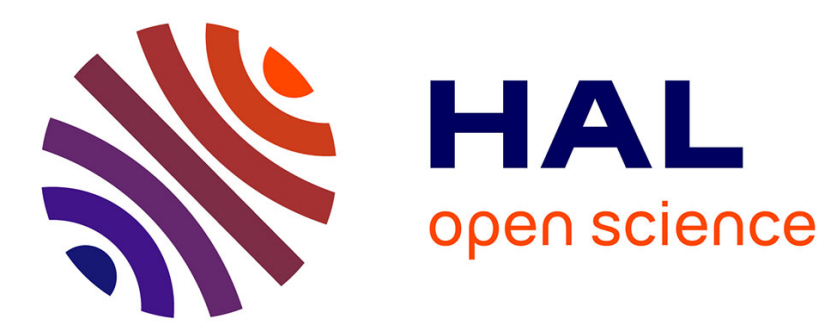

\title{
Poly 3,4-ethylenedioxythiophene as an entrapment support for amperometric enzyme sensor
}

Silvia Fabiano, Canh Tran-Minh, Benoît Piro, Lan Anh Dang, Minh Chau Pham, Olivier Vittori

\section{- To cite this version:}

Silvia Fabiano, Canh Tran-Minh, Benoît Piro, Lan Anh Dang, Minh Chau Pham, et al.. Poly 3,4ethylenedioxythiophene as an entrapment support for amperometric enzyme sensor. Materials Science and Engineering: C, 2002, 21 (1-2), pp.61-67. 10.1016/S0928-4931(02)00060-7 . emse-00520323

HAL Id: emse-00520323

https://hal-emse.ccsd.cnrs.fr/emse-00520323

Submitted on 18 Oct 2010

HAL is a multi-disciplinary open access archive for the deposit and dissemination of scientific research documents, whether they are published or not. The documents may come from teaching and research institutions in France or abroad, or from public or private research centers.
L'archive ouverte pluridisciplinaire $\mathbf{H A L}$, est destinée au dépôt et à la diffusion de documents scientifiques de niveau recherche, publiés ou non, émanant des établissements d'enseignement et de recherche français ou étrangers, des laboratoires publics ou privés. 


\title{
Poly 3,4-ethylenedioxythiophene as an entrapment support for amperometric enzyme sensor
}

\section{Silvia Fabiano(1), Canh Tranh Minh(1), Benoît Piro ${ }^{(2)}$, Lan ANh Dang( ${ }^{(2)}$, Minh CHAU PHAM( ${ }^{(2)}$, OLIVIER VITTORI(3)}

(1) Ecole Nationale Supérieure des Mines de Saint Etienne, Centre SPIN ; Département PMMC ; 158, Cours Fauriel ; 42023 Saint-Étienne Cedex 2, France

(2) ITODYS-CNRS-UMR 7086 ; Université Paris 7-Denis Diderot ; 1, rue Guy de la Brosse, 75005, Paris, France

(3) Université Claude Bernard Lyon I/Ecole Supérieure de Chimie Physique et Electronique de Lyon ; Laboratoire d'Electrochimie Analytique ; 43 Boulevard du 11 novembre, 69622, Villeurbanne Cedex, France

\begin{abstract}
A conducting polymer of poly 3,4-ethylenedioxythiophene (PEDT) was used as a matrix for entrapment of enzymes onto a platinum electrode surface in order to construct amperometric biosensors. Glucose oxidase (GOD) was used as an example, and it was entrapped in the polymer during the electrochemical polymerization. Glucose in oxygenated solutions was tested by amperometric measurements at $+650 \mathrm{mV}$ (vs. SCE) in a batch system. The influence of several experimental parameters in the electropolymerization process was explored to optimize the analytical performance.

The detection limit and sensitivity for this biosensor were $4 \times 10^{-5} \mathrm{M}$ and $15.2 \mathrm{~mA} \mathrm{M}^{-1} \mathrm{~cm}^{-2}$, respectively. A linear range of response was found from 0.2 to $8 \mathrm{mM}$ of glucose. The response time was $2-5 \mathrm{~s}$. The stability of the electropolymerized films was evaluated in operational conditions. The glucose probe, stored in buffer at $4{ }^{\circ} \mathrm{C}$ when not in use, showed a residual activity of $40 \%$ after about 1 month. Glucose in synthetic serum was determined under flow injection conditions using an amperometric flow cell.
\end{abstract}

Keywords:

Electropolymerization; Conducting polymer; Glucose enzyme electrodes; FIA

\section{Introduction}

Amperometric enzyme electrodes have generally been constructed by direct immobilization of oxidoreductases on electrode surfaces. Platinum, gold, graphite or glassy carbon electrodes have been used. They often have produced unstable responses attributed to a poor charge transfer between the electrode and the enzymes. This is due to the fact that biocatalytic sites are usually buried in the inner part of the enzymatic protein [1]. Therefore, natural or artificial redox mediators are added in the soluble [2] or immobilized [3] form to shuttle the electrons between the various redox chemicals involved in the oxidoreductase process [4]. Conducting polymers have also been used in amperometric enzyme electrodes with the intention to couple the electron transfer reaction between enzyme and electrode via the ramified conducting network of the polymer [2, 5 and 6]. They could also have appropriate functional groups to which allowed enzymes can be attached. Finally, many conducting polymers can be deposited electrochemically [7]. In most polymers such as polypyrrole [8, 9, 10, 11, 12, 13, 14 and 15], polyaniline [16, 17 and 18] and polythiophene [19 and 20], redox charges are delocalised over some polymer groups that could facilitate the oxidation-reduction processes. Among the promising family of polythiophenes, poly 3,4-ethylenedioxythiophene (PEDT) shows remarkable stability, provides homogeneous films [21] and can be synthesized electrochemically even in aqueous medium [22]. Oligonucleotides have then been 
incorporated into PEDT films by electrochemical method [23]. Therefore, we recently used PEDT to covalently attach glucose oxidase (GOD) onto a glassy carbon electrode to obtain an enzyme electrode for glucose sensing [24]. In this paper, this polymer is directly electrogenerated on a platinum electrode to produce thin films for a single-step entrapment of the enzyme. The amperometric biosensor obtained from this technique is designed to be integrated in a flow injection system to determine glucose in real samples.

Amperometric flow injection analysis (FIA) associated with immobilized enzyme sensor has become recognized as a selective, simple, accurate and rapid technique for the determination of a variety of biologically important compounds [25]. In such a system, solid electrode-based detectors are commonly used for the detection of electroactive products generated enzymatically. This system offers advantages of highly reproducible timing and high sample throughput and eliminates the need to attain steady states [26]. As the PEDT biosensor has never been tested in FIA conditions, the PEDT biosensor described in this paper is therefore integrated in a FIA equipment to determine the performance of this coupling.

In order to construct the amperometric enzyme sensor, glucose oxidase is used as an example of a redox protein. The enzyme catalyses, in the presence of molecular oxygen, the oxidation of $\beta$ - ${ }^{-}$-glucose into gluconic acid and hydrogen peroxide. The conversion of $\beta$ - $^{-}$-glucose to gluconic acid involves the transfer of two protons and two electrons from the substrate to the flavin moiety of the enzyme [27]. The electron transfer from the redox cofactor to the sensing electrode might also be facilitated by the presence of a polymeric conducting material.

\section{Experimental}

\section{II.1. Chemicals}

3,4-Ethylenedioxythiophene monomer (EDT) was kindly provided by Bayer (France). Polyethylene glycol (PEG) of 15,000 MW was purchased from Aldrich. -(+)-Glucose and glucose oxidase (EC 1.1.3.4.) type VII from Aspergillus niger were purchased from Sigma (France) and used as received. Accutrol ${ }^{\mathrm{TM}}$ normal chemistry control serum was purchased from Sigma. All other chemicals were of analytical grade.

Glucose solutions were allowed to mutarotate overnight at room temperature before use. Phosphate buffer was prepared using dihydrogen phosphate dihydrate (Prolabo, France). pH was adjusted with sodium hydroxide solution. All solutions were prepared using milliQß pure water (Millipore, France).

\section{II.2. Apparatus}

Voltammetric and amperometric measurements were performed using a Tacussel PGP 201 potentiostat. The potentiostat output was recorded and processed by means of a Volta Master 1 software. The electrochemical cell was a three-electrode cell where the PEDT/GOD-modified platinum disk electrode acted as the working electrode and a platinum wire as the counter electrode. All potentials were measured vs. SCE. The working electrodes were constructed using a BAS $₫$ platinum electrode with a disk-shaped active surface with a diameter of $1.6 \mathrm{~mm}$ for batch system and a diameter of $3 \mathrm{~mm}$ for flow injection system. A miniaturized flow cell from BAS $\AA$ was used for FIA measurements (Figure 1). One side of the flow cell contains the inlet and outlet cannulas, the auxiliary electrode and the reference electrode. The other side holds the working electrode. The reference electrode is an electrode without porous junction. It consists of silver metal (Ag) coated with a layer of silver chloride salt ( $\mathrm{AgCl}$ ). The auxiliary electrode is an adjacent 2-mm stainless-steel disk. The inlet cannula is connected to the source of the flow stream, and the outlet cannula is directed to a waste container. The flow system volume using a $51-\mu \mathrm{m}$-thick Teflon gasket is $6.9 \mu \mathrm{l}$.

All the lines were made from a $0.41-\mathrm{mm}$ internal diameter Teflon tubing. A sample line was used to fill the sample loop on a Rheodyne (USA) sample injection valve that was used to inject samples into a buffer stream. An Ismatec peristaltic pump (Switzerland) was used in conjunction with an injection valve. 


\section{II.3. Immobilization procedure}

Bare electrodes used for preparing the biosensors consisted of Pt disks. The working electrode surface was polished before use with alumina (polishing alumina fluid provided by BAS®, England) of $0.05 \mu \mathrm{m}$ particle size. After careful rinsing with distilled water, the electrodes were pretreated by potential cycling in $0.5 \mathrm{M} \mathrm{H}_{2} \mathrm{SO}_{4}$ from -1500 to $+1500 \mathrm{mV}$ (vs. SCE) at a scan rate of $2 \mathrm{~V} / \mathrm{s}$ until no changes were observed in the cyclic voltammograms.

A film of enzymatic PEDT was deposited on the Pt electrode by electropolymerizing 3,4ethylenedioxythiophene (EDT) through cyclic voltammetry. A $10^{-2} \mathrm{M}$ solution of EDT was obtained by dissolving EDT in a 0.02-M, pH 6.2 phosphate buffer solution containing $10^{-3} \mathrm{M}$ PEG and 1000 IU glucose oxidase $\mathrm{ml}^{-1}$. Electrochemical growth of PEDT was carried out using potential cycling between +200 and $+1500 \mathrm{mV}$ at a scan rate of $0.1 \mathrm{~V} / \mathrm{s}$ for a total of 15 cycles. The same immobilization procedures were used to construct glucose enzyme sensor for batch and flow injection systems.

\section{II.4. Batch measurements}

For the batch amperometric measurement of glucose, the PEDT/GOD biosensor was dipped in a 20-ml beaker containing $10 \mathrm{ml}$ of potassium phosphate buffer solution. The electrochemical cell was completed with a SCE reference electrode and a platinum wire counter electrode. The solution was continuously stirred in the open air with a magnetic stirrer to maintain a constant oxygen concentration in the solution for the enzymatic reaction to operate properly. The temperature was controlled using a thermostat (Lauda-Thermostat, Germany). After the cell was assembled, a potential of $+650 \mathrm{mV}$ was applied to the working electrode to detect hydrogen peroxide. When a baseline was reached, glucose was spiked. The current generated on the biosensor was measured when a steady state was reached. Unless otherwise stated, all experiments were carried out at $25^{\circ} \mathrm{C}$, with an applied potential of +650 $\mathrm{mV}$ vs. SCE, in a sodium phosphate buffer (0.01 M, pH 7.0) containing $0.1 \mathrm{M} \mathrm{KCl}$.

\section{II.5. Flow injection measurements}

The configuration of the FIA manifold has already been described [28]. A peristaltic pump was used to transport the carrier liquid and inject the sample and an injection valve with a loop to receive sample and carrier liquid alternately. The determination of glucose was obtained with a biosensor placed in a miniaturized flow cell. An potential of $+650 \mathrm{mV}$ vs. $\mathrm{Ag} / \mathrm{AgCl}$ was applied to the amperometric enzyme electrode by means of a potentiostat connected to a recorder. In this method, time, temperature and dispersion were all reproducible conditions. The peristaltic pump operated with a $75 \mu \mathrm{l} \mathrm{min} \mathrm{m}^{-1}$ flow rate of a carrier stream of potassium phosphate buffer (0.01 M, pH 7.0) containing $0.1 \mathrm{M} \mathrm{KCl}$. The volume of injection loop was $50 \mu$. The response curve appears in the form of peaks whose heights depend on the substrate concentration. The concentration of the analyte in a sample can thus be determined from a calibration curve setup with known substrate standards in duplicate measurements.

\section{Results and discussion}

\section{III.1. Optimization of the enzyme immobilization}

Current-potential curves at steady state for glucose are shown in Figure 2. The current response increases as soon as the potential is over $+200 \mathrm{mV}$ and a plateau is reached at +500 $\mathrm{mV}$. Therefore, $+650 \mathrm{mV}$ was chosen as the working potential for glucose determination. It corresponds to the oxidation of $\mathrm{H}_{2} \mathrm{O}_{2}$ produced by the enzyme-substrate reaction.

To control the electroentrapment of the enzyme, electropolymerization of this solution was carried out using a number of voltammetric cycles: The first cycles were applied to induce the polymerization process and the following cycles to achieve the overall coating of the electrode. Fifteen cycles were found sufficient to ensure an effective enzyme immobilization, too many cycles would have deleterious effects on mechanical properties of the polymer layer [23]. The thickness of the polymer film can be controlled by the charge consumed in the polymerization 
of the monomer. The enzyme concentration has little effect on the membrane thickness because the matrix is mainly represented by PEDT [2].

The influence of enzyme loading in the polymer on the sensor response to glucose was examined (Figure 3). Responses of the PEDT/GOD biosensor to $5 \mathrm{mM}$ glucose increase when the enzyme concentration in the electropolymerization solution increases from 50 to 800 IU $\mathrm{ml}^{-1}$ and reach a plateau at $800 \mathrm{IU} \mathrm{ml} \mathrm{m}^{-1}$ corresponding to the enzyme saturation in the solution. However, a $1000 \mathrm{IU} \mathrm{ml}^{-1}$ concentration, which is the saturation limit, was adopted for enzyme immobilization in case of enzyme activity loss during electropolymerization. A specific activity of immobilized GOD is estimated to be $0.4 \mathrm{IU} / \mathrm{ml}$ from spectrophotometric determination of glucose oxidase activity described elsewhere.

\section{III.2. Response of the biosensor in a batch system}

Figure 4 shows steady-state amperometric responses of the PEDT/GOD biosensor to the addition of aliquots of the stock glucose solution into an air-saturated phosphate buffer solution in a batch system. Oxygen concentration should be kept constant because it is a cosubstrate of the enzymatic reaction. These responses are used to construct a calibration curve for glucose. Although a time lag is necessary for the sample solution to be homogeneous after substrate addition, a rapid response of the PEDT/GOD biosensor is observed for each glucose concentration: $2-5 \mathrm{~s}$ is estimated to reach a stable plateau.

The enzyme electrode calibration curve using a PEDT film is presented in Figure 5. The data are obtained from measurements repeated three times for each concentration, and the mean value is reported in this figure. The linear range of the biosensor response to glucose concentration from 0.2 up to $8 \mathrm{mM}$ would allow to determine human blood glucose, which lies within the narrow limits of 3.5-5.0 mM. The detection limit of the enzyme electrode is 40 $\mu \mathrm{M}$, which corresponds to a signal-to-noise ratio of 3 . The sensitivity corresponding to the linear range is about $15.2 \mathrm{~mA} \mathrm{M} \mathrm{m}^{-1} \mathrm{~cm}^{-2}$. This sensitivity gradually decreases at higher glucose concentrations.

\section{III.3. Effects of $\mathrm{pH}$}

The effect of $\mathrm{pH}$ of the electropolymerization solution on the amperometric response of the PEDT/GOD electrode was studied for pHs ranging from 5 to 8 (Figure 6). Optimum response to $5 \mathrm{mM}$ of glucose was observed for an electropolymerization at $\mathrm{pH}$ 6.2. This $\mathrm{pH}$ value was previously adopted for polymerization of the same polymer [21]. An optimized polymerization $\mathrm{pH}$ should allow an efficient entrapment of the enzyme while preventing loss of enzyme activity under polymerization conditions. PEG was added to the EDT solution to improve the enzyme activity by increasing the hydrophicity of the polymer.

The enzyme sensor response also depends on the working $\mathrm{pH}$ of the sampling solution. The effect of $\mathrm{pH}$ on the behaviour of the enzyme electrode was studied with $0.01 \mathrm{M}$ phosphate buffer solution containing $5 \mathrm{mM}$ glucose. The $\mathrm{pH}$ of the solution ranges from 5 to 8 . The response of biosensor as a function of working $\mathrm{pH}$ is shown in Figure 6. A maximal response is obtained for $\mathrm{pH}$ 7.0, which is different from the optimal electropolymerization $\mathrm{pH}$ and higher than the optimal $\mathrm{pH}$ of glucose oxidase dissolved in a solution which has been reported as 5.6 [29]. In fact, the kinetics of immobilized enzyme is different from the enzyme kinetics in a homogeneous solution. On the biosensor where the diffusion-reaction process should be taken into account, the oxidation of glucose by immobilized glucose oxidase in the active layer produces gluconic acid, which decreases the local value of $\mathrm{pH}$. The $\mathrm{pH}$ value in the enzyme layer bound to the electrode then is lower than the $\mathrm{pH}$ of the bulk solution. In order to have the enzyme optimal $\mathrm{pH}$ in the PEDT film containing GOD, a higher $\mathrm{pH}$ is necessary in the sample solution.

\section{III.4. Stability}

Thermal stability of the enzyme electrode was investigated up to $50^{\circ} \mathrm{C}$. The response of the PEDT/GOD electrode to glucose increases with temperature from 15 to $30{ }^{\circ} \mathrm{C}$, then a decrease in enzyme activity is observed (Figure 7). A $25{ }^{\circ} \mathrm{C}$ temperature is adopted in our experiments in order to prevent any risk of enzyme denaturation. 
The main objective of enzyme immobilization on a transducer for analytical purposes is to stabilise the enzyme for the biosensor to be used repeatedly over a long period. The long-term stability of a biosensor is then tested everyday with the PEDT/GOD electrode. The biosensor was stored between measurements in a phosphate buffer solution at $4{ }^{\circ} \mathrm{C}$. This testing procedure is carried out with a $5-\mathrm{mM}$ glucose solution over 4 weeks. The enzyme electrode retained about $40 \%$ of its initial activity after 25 days (Figure 8 ).

\section{III.5. Flow injection system for the determination of glucose in synthetic serum sample}

The batch system previously described is quite suitable to study the effects of $\mathrm{pH}$ and temperature on the response of the biosensor as well as its long-term stability. In such a system, the various parameters can easily be adjusted and controlled in order to allow normal working conditions of the biosensor to be optimized.

In biochemical analysis, the need of high sample throughput requires continuous measurements and limitation of manual handling. FIA associated with a biosensor provides a fast, reliable and continuous method to determine glucose without any additional reagent.

Repeatability of FIA measurements is conducted with injections of glucose in duplicate at various concentrations (Figure 9). A mean RSD value of $3.7 \%$ is obtained from those responses.

Figure 10 shows typical calibration graph for glucose. A linear relationship between the signal and the concentration is observed up to $10 \mathrm{mM}$ for glucose. The sensitivity calculated from the linear range is about $7.8 \mathrm{~mA} \mathrm{M}^{-1} \mathrm{~cm}^{-2}$.

The detection limit with this FIA biosensor is $5 \mu \mathrm{M}$ for a glucose concentration corresponding to a signal-to-noise ratio of 3 . This good detection limit is due to a very stable baseline: It is eight times lower than that obtained from the batch system.

Monitoring of glucose in blood is important for diagnosis and surveillance of diabetes, the assays should also be conducted with glucose in serum samples to assess the practical applicability of this method. In this work, the control human serum used consists of an assayed lyophilized preparation containing the analytes commonly observed in man following physiological or pharmacological intakes. Some electroactive species except ascorbic acid are present in this control serum at their usual concentrations: acetaminophen $(86-139 \mu \mathrm{M})$, salicylate $(0.5-0.8 \mathrm{mM})$ and uric acid $(321-393 \mu \mathrm{M})$.

Table 1 shows the results obtained from this FIA biosensor in comparison with others techniques used to determine glucose in human control serum. Assigned means are of replicate assays performed in reference laboratories using the indicated procedure. The concentrations obtained with this FIA biosensor are similar to those given by other procedures.

\section{Conclusion}

In this study, the possibility of using conducting polymer as a support for single-step immobilization of glucose oxidase has been investigated. The use of PEDT as an entrapment support of glucose oxidase in the development of a glucose biosensor is motivated by the conductivity and stability properties of PEDT [21, 30, 31 and 32]. We have shown that electrochemical polymerization of EDT results in an efficient technique to immobilize glucose oxidase onto a platinum electrode surface. The batch system provides an easy method to optimize the various operating parameters of the biosensor. Its rapid response time and stability are compatible with its application in flow analysis systems. The determination of human blood glucose is possible due to its wide dynamic range.

In spite of a large number of species present in control human serum, the results given by the FIA/biosensor are in agreement with those obtained from other methods currently in use. This immobilization technique, which can be extended to other oxidoreductases, is quite suitable for the design and construction of microbiosensors. 


\section{References}

[1] P.N. Bartlett and P.R. Birkin Synth. Met. 61 (1993), p. 15.

[2] W. Schuhmann Mikrochim. Acta 121 (1995), p. 1.

[3] T.W. Lewis, G.G. Wallace and M.R. Smyth Analyst 124 (1999), p. 213.

[4] J. Wang J. Pharm. Biomed. Anal. 19 (1999), p. 47.

[5] Y. Liu and T. Yu Rev. Macromol. Chem. Phys. C 373 (1997), p. 459.

[6] N.C. Foulds and C.R. Lowe Anal. Chem. 60 (1988), p. 2473.

[7] S.A. Emr and A.M. Yacynych Electroanalysis 7 (1995), p. 913.

[8] S. Cosnier and A. Lepellec Electrochim. Acta 44 (1999), p. 1833.

[9] S. Cosnier Electroanalysis 9 (1997), p. 894.

[10] D. Bélanger, J. Nadreau and G. Fortier J. Electroanal. Chem. 274 (1989), p. 143.

[11] G. Fortier, E. Brassard and D. Bélanger Biosens. Bioelectron. 5 (1990), p. 473.

[12] G. Fortier and D. Bélanger Biotechnol. Bioeng. 37 (1991), p. 854.

[13] M.J. Swann, D. Bloor, T. Haruyama and M. Aizawa Biosens. Bioelectron. 12 (1997), p. 1169.

[14] L. Coche-Guerente, S. Cosnier, C. Innocent and P. Mailley Anal. Chim. Acta 311 (1995), p. 23.

[15] W. Schuhmann, C. Kranz, J. Huber and H. Wohlschläger Synth. Met. 61 (1993), p. 31.

[16] M. Trojanowics, O. Geschke, T.K. Krawczyk and K. Cammann Sens. Actuators, B, Chem 28 (1995), p. 191.

[17] S. Mu and H. Xue Sens. Actuators, B, Chem 31 (1996), p. 155.

[18] S. Lu, C. Li, D. Zhang, Y. Zhang, Z. Mo, Q. Cai and A. Zhu J. Electroanal. Chem. 364 (1994), p. 31.

[19] M. Hiller, C. Kranz, J. Huber, P. Bäuerle and W. Schuhmann Adv. Mater. 83 (1996), p. 219.

[20] G. Zotti, S. Zecchin and G. Schiavon Chem. Mater. 7 (1995), p. 2309.

[21] H. Yamato, M. Ohwa and W. Wernet J. Electroanal. Chem. 397 (1995), p. 163.

[22] S. Garreau, G. Louarn, J.P. Buisson, G. Froyer and S. Lefrant Macromolecules 32 (1999), p. 6807.

[23] B. Piro, M.C. Pham and T. Ledoan Biomat. Res. 464 (1999), p. 566.

[24] B. Piro, L.A. Dang, M.C. Pham, S. Fabiano and C. Tran-Minh J. Electroanal. Chem. 512 (2001), p. 101.

[25] T. Yao, M. Satomura and T. Nakahara Anal. Chim. Acta 296 (1994), p. 271.

[26] S. Kumaran and C. Tran-Minh Anal. Biochem. 200 (1992), p. 187.

[27] A. Haouz, C. Twist, C. Zents, P. Tauc and B. Alpert Eur. Biophys. J. 27 (1998), p. 19.

[28] C. Tran-Minh, Biosensors. , Chapman \& Hall, London (1993).

[29] T. Barman In: Enzyme Handbook vol. 1, Springer-Verlag, Berlin, Heidenberg (1969), p. 112.

[30] K. Lerch, F. Jonas and M. Linke J. Chim. Phys. 95 (1998), p. 1506.

[31] G. Heywang and F. Jonas Adv. Mater. 42 (1992), p. 116.

[32] R. Jolly, S. Pairis and C. Pétrescu J. Chim. Phys. 95 (1998), p. 1400. 
Materials Science and Engineering C, 2002, 21(1-2), 61-67, doi:10.1016/So9284931(02)00060-7

\section{Figures}

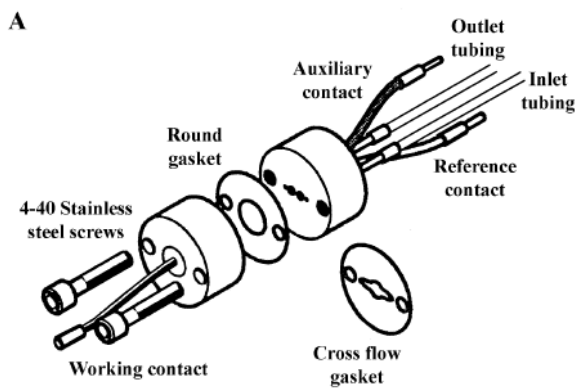

B

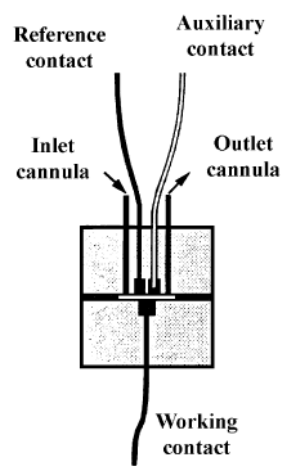

Figure 1: Configuration (A) and side view (B) of a miniaturized amperometric flow cell.

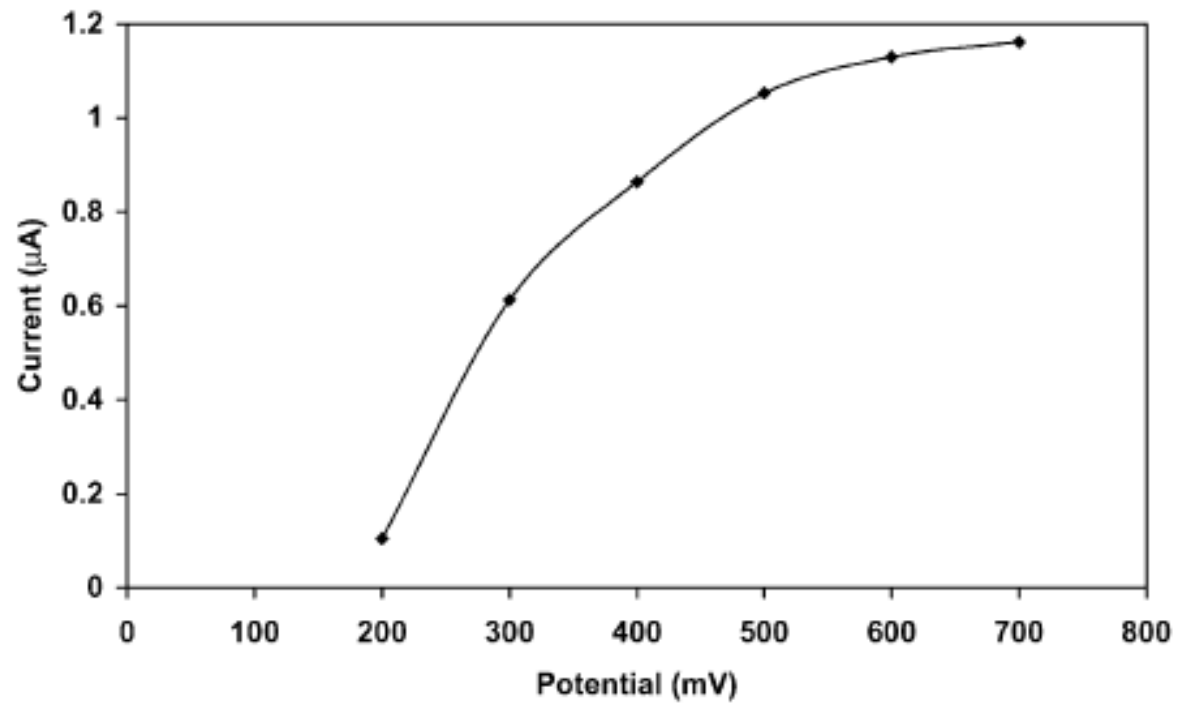

Figure 2: Hydrodynamic voltammogram of a glucose solution using a PEDT/GOD electrode. Conditions: $5 \mathrm{mM}$ glucose, $0.01 \mathrm{M}, \mathrm{pH} 7.0$ sodium phosphate buffer and $0.1 \mathrm{M} \mathrm{KCl,} 25^{\circ} \mathrm{C}$. 
Materials Science and Engineering C, 2002, 21(1-2), 61-67, doi:10.1016/So9284931(02)00060-7

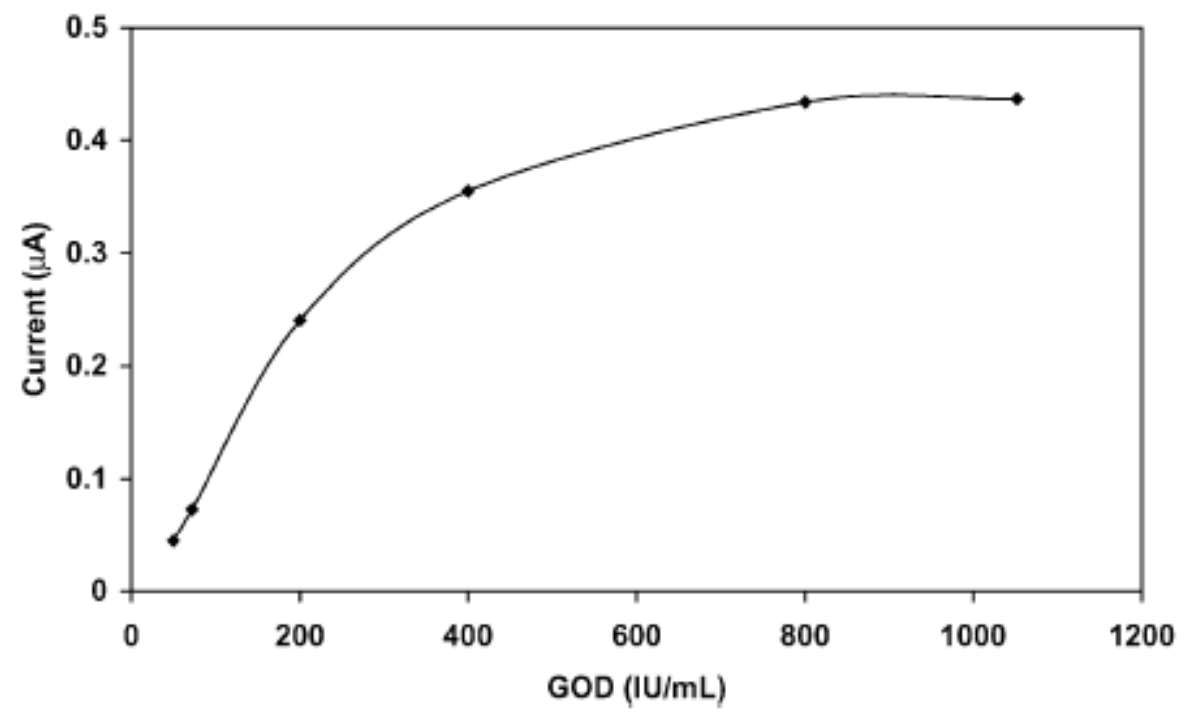

Figure 3: Effect of enzyme concentration on the PEDT/GOD electrode response to glucose. Conditions: $5 \mathrm{mM}$ glucose, $0.01 \mathrm{M}, \mathrm{pH} 7.0$ sodium phosphate buffer and $0.1 \mathrm{M} \mathrm{KCl,} 25^{\circ} \mathrm{C}$, $+650 \mathrm{mV}$ vs. SCE.

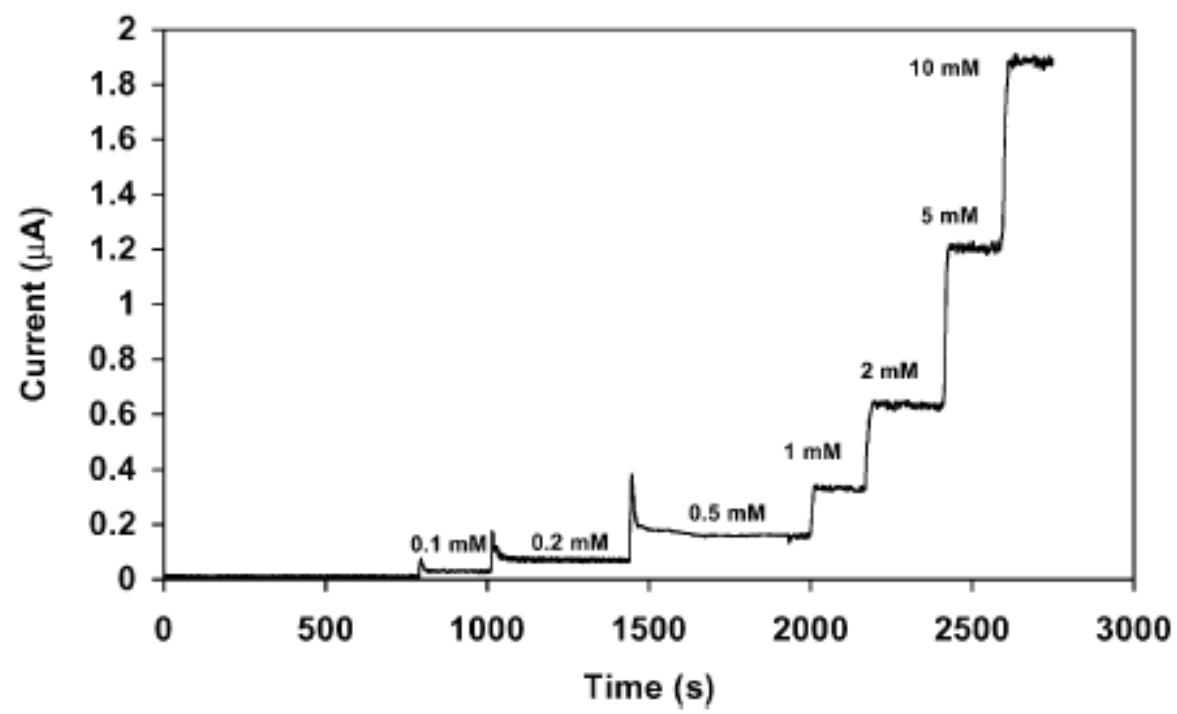

Figure 4: Typical responses of a PEDT/GOD electrode to glucose in an air-satured buffer. Conditions: o.o1 M, pH 7.o sodium phosphate buffer and $0.1 \mathrm{M} \mathrm{KCl,} 25^{\circ} \mathrm{C}$, +65O $\mathrm{mV}$ vs. SCE. 
Materials Science and Engineering C, 2002, 21(1-2), 61-67, doi:10.1016/So9284931(02)00060-7

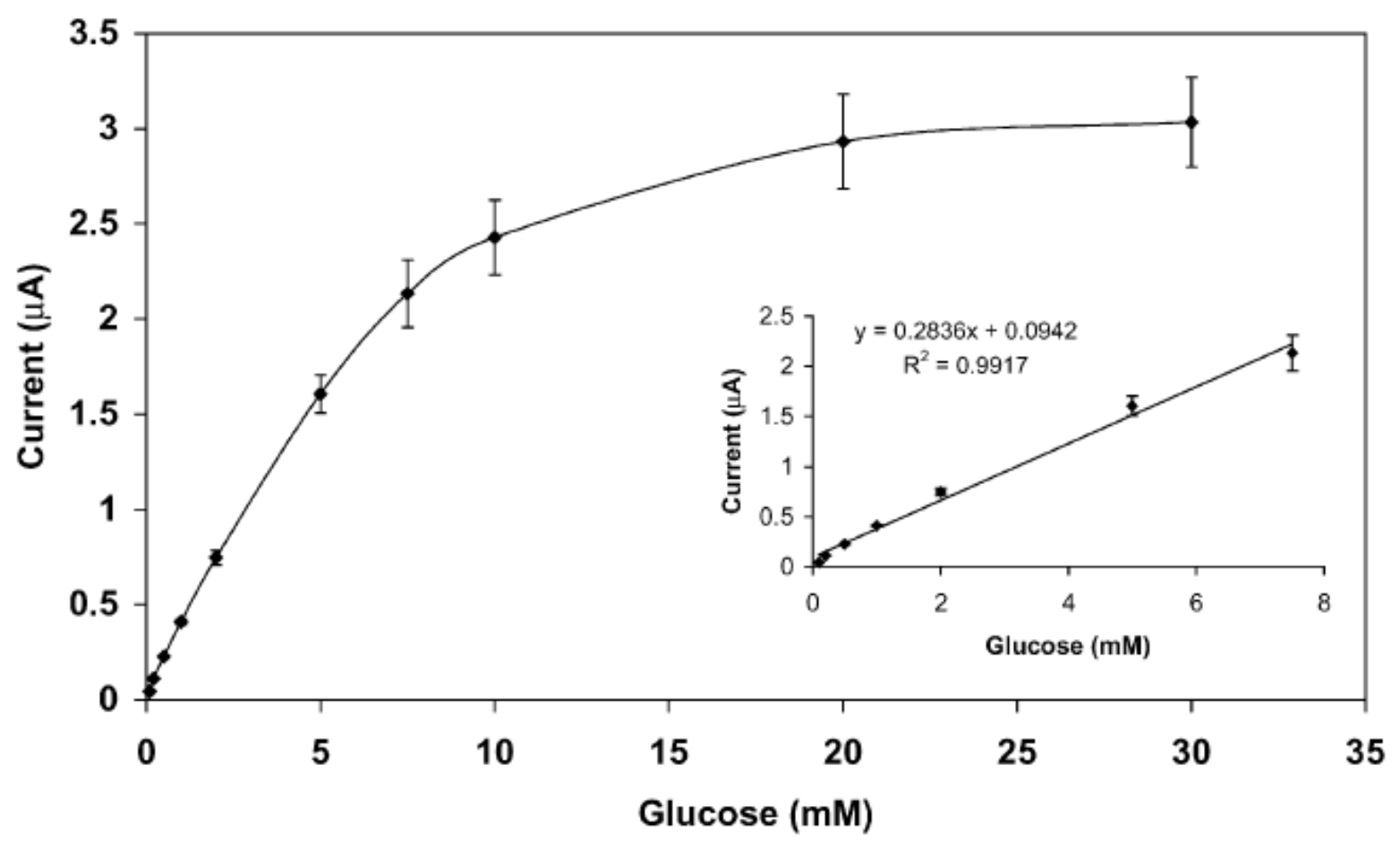

Figure 5: Calibration curve of a Pt/PEDT/GOD electrode sensitive to glucose. Conditions: o.o1 M, pH 7.o sodium phosphate buffer and $0.1 \mathrm{M} \mathrm{KCl}, 25^{\circ} \mathrm{C},+650 \mathrm{mVvs}$. SCE.

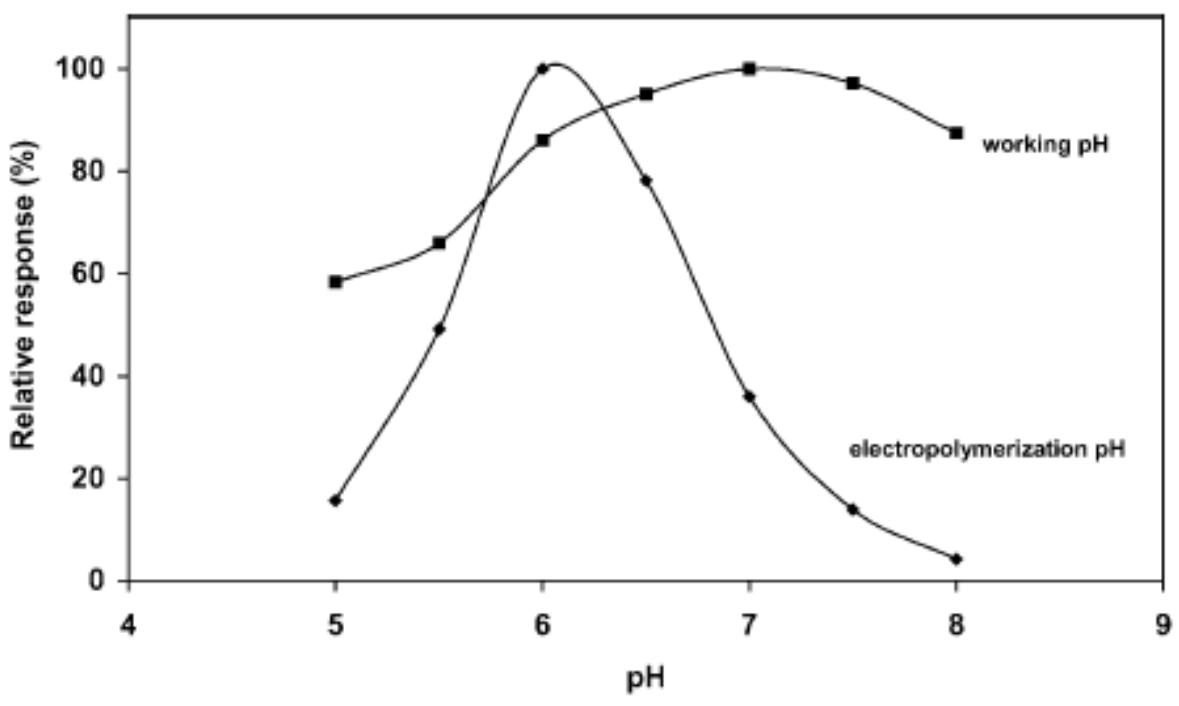

Figure 6: Effect of electropolymerization and working pHs on the PEDT/GOD electrode response to glucose. Conditions: $5 \mathrm{mM}$ glucose, $0.01 \mathrm{M}$ sodium phosphate buffer and $0.1 \mathrm{M} \mathrm{KCl}, 25^{\circ} \mathrm{C},+650 \mathrm{mVvs}$. SCE. 
Materials Science and Engineering C, 2002, 21(1-2), 61-67, doi:10.1016/So9284931(02)00060-7

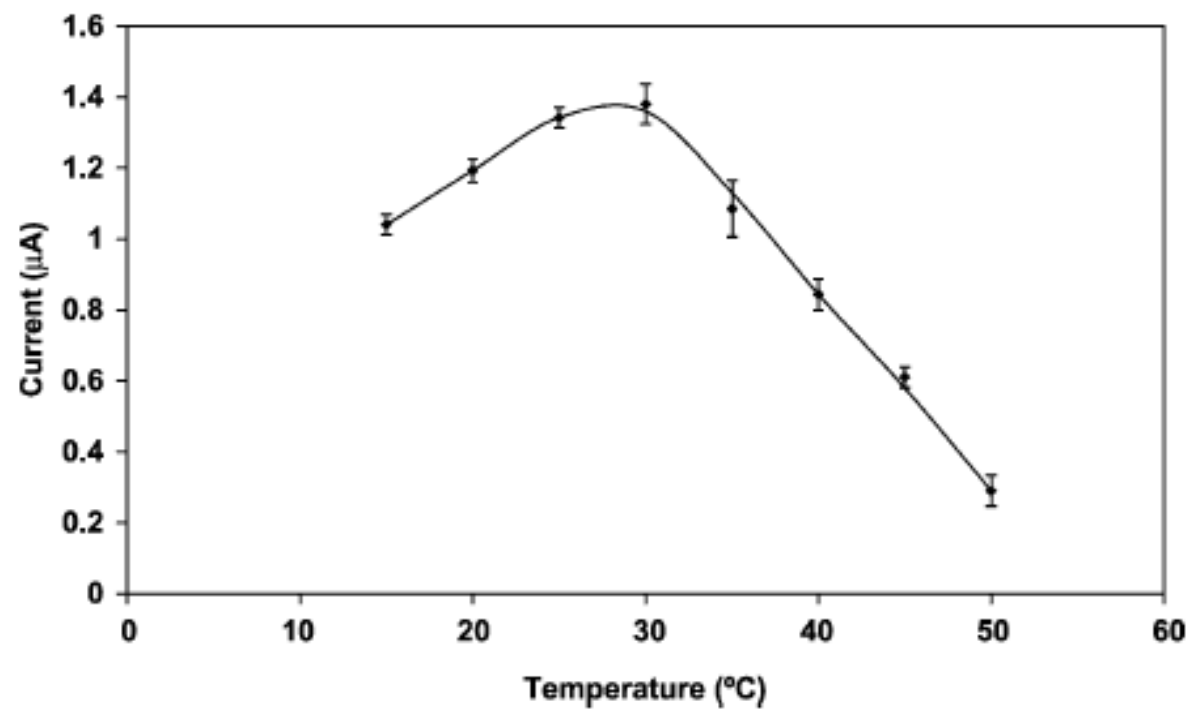

Figure 7: Effect of temperature on the PEDT/GOD electrode response to glucose. Conditions: $5 \mathrm{mM}$ glucose, o.o1 $\mathrm{M}, \mathrm{pH} 7 . \mathrm{O}$ sodium phosphate buffer and $0.1 \mathrm{M} \mathrm{KCl},+650 \mathrm{mV} v \mathrm{~s} . \mathrm{SCE}$.

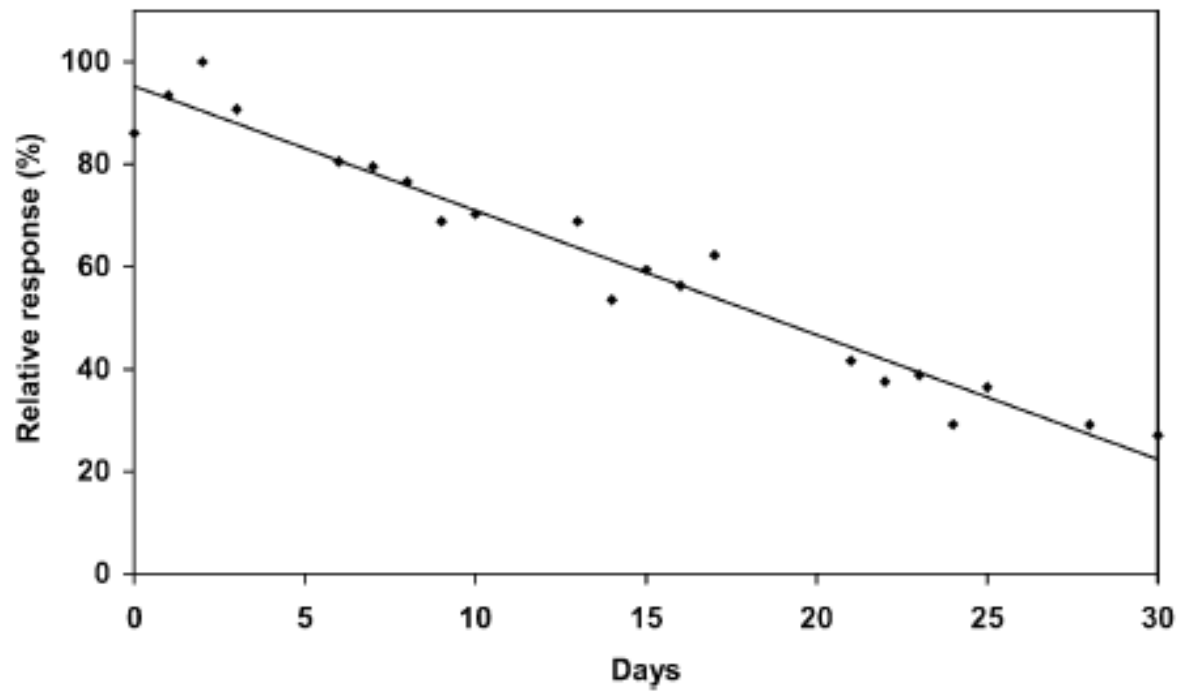

Figure 8: Long term stability of a PEDT/GOD electrode. Conditions: 5 mM glucose, o.o1 M, pH 7.o sodium phosphate buffer and $0.1 \mathrm{M} \mathrm{KCl,} 25^{\circ} \mathrm{C},+650 \mathrm{mV} v \mathrm{~s}$. SCE. 
Materials Science and Engineering C, 2002, 21(1-2), 61-67, doi:10.1016/So9284931(02)00060-7

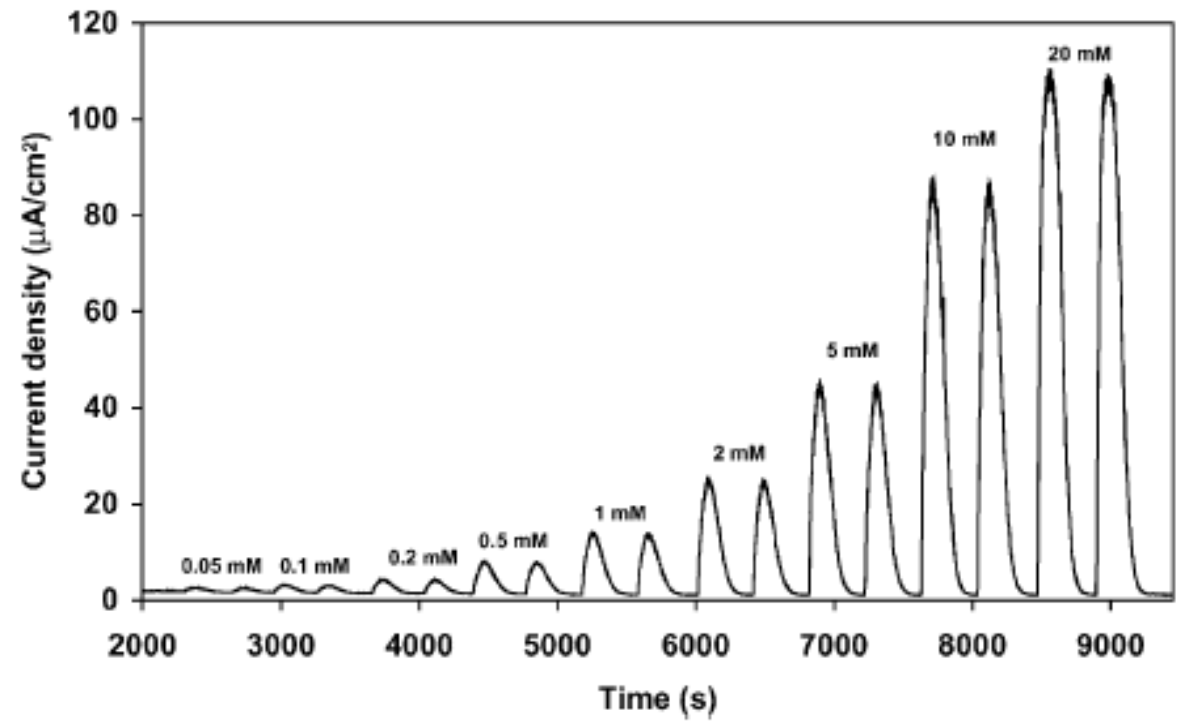

Figure 9: Flow injection analysis of the biosensor to various injections of glucose samples in duplicate. Conditions: $0.01 \mathrm{M}, \mathrm{pH}$ 7.0 sodium phosphate buffer and $0.1 \mathrm{M} \mathrm{KCl}, 25^{\circ} \mathrm{C},+65 \mathrm{O} \mathrm{mV} \mathrm{vs.} \mathrm{Ag} / \mathrm{AgCl}, 75 \mu \mathrm{min}{ }^{-1}$ flow rate.

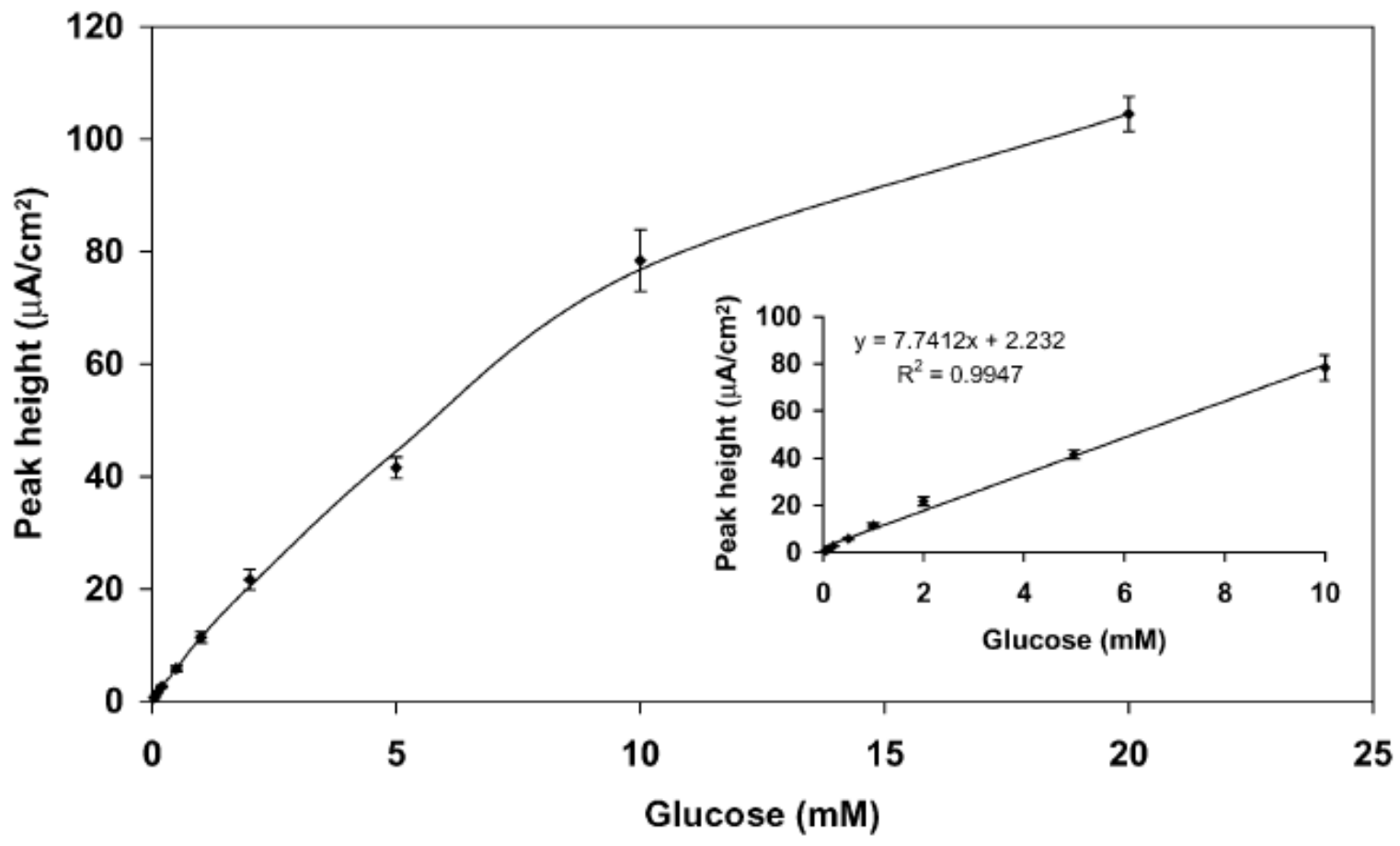

Figure 10: Calibration plot in FIA determination of glucose with the FIA/biosensor. Conditions: o.o1 M, pH 7.o sodium phosphate buffer and $0.1 \mathrm{M} \mathrm{KCl}, 25^{\circ} \mathrm{C},+650 \mathrm{mVvs}$. $\mathrm{Ag} / \mathrm{AgCl}$. 
Materials Science and Engineering C, 2002, 21(1-2), 61-67, doi:10.1016/So9284931(02)00060-7

\section{Tables}

Table 1: Comparison of the results obtained with this FIA/biosensor to those obtained with standards glucose kits, in serum glucose analysis

\begin{tabular}{|l|l|l|l|}
\hline Method & SIU unit & SIU Mean & SIU Range \\
\hline $\begin{array}{l}\text { Abbott Spectrum/VP series } \\
\text { (hexokinase) }\end{array}$ & $\mathrm{mmol} / \mathrm{l}$ & 4.9 & $4.4-5.4$ \\
\hline $\begin{array}{l}\text { Bayer-Opera/RA series } \\
\text { (hexokinase/340 nm) }\end{array}$ & $\mathrm{mmol} / \mathrm{l}$ & 5.0 & $4.5-5.5$ \\
\hline $\begin{array}{l}\text { Beckman-CX/LX/Synchron } \\
\text { series (hexokinase) }\end{array}$ & $\mathrm{mmol} / \mathrm{l}$ & 4.8 & $4.3-5.3$ \\
\hline $\begin{array}{l}\text { BioChem-ATAC } \\
\text { (hexokinase/340 nm) }\end{array}$ & $\mathrm{mmol} / \mathrm{l}$ & 5.3 & $4.7-5.9$ \\
\hline Ortho-Vitros (oxidase) & $\mathrm{mmol} / \mathrm{l}$ & 4.8 & $4.3-5.3$ \\
\hline Pointe Scientific (oxidase) & $\mathrm{mmol} / \mathrm{l}$ & 5.0 & $4.5-5.5$ \\
\hline $\begin{array}{l}\text { Roche-Cobas Mira series } \\
\text { (hexokinase/340 nm) }\end{array}$ & $\mathrm{mmol} / \mathrm{l}$ & 4.6 & $4.2-5.0$ \\
\hline Sigma (enzymatic, Trinder) & $\mathrm{mmol} / \mathrm{l}$ & 4.7 & $3.7-5.7$ \\
\hline Present FIA biosensor & $\mathrm{mmol} / \mathrm{l}$ & 4.1 & $3.9-4.3$ \\
\hline
\end{tabular}

${ }^{a}$ System of International Units. 